\title{
A Study on Efficacy of Helical Tomotherapy Combined With Concurrent Chemotherapy \pm EGFR Inhibitor After Induction Chemotherapy In Patients Affected By Locally Advanced Nasopharyngeal Carcinoma (LANC) With Carotid Artery Invasion And Risk Analysis of Massive Bleeding After Radiotherapy
}

\author{
KUN LIU \\ General Hospital of PLA \\ Jian Wei \\ Chinese PLA General Hospital \\ qing sen Wang \\ Chinese PLA General Hospital \\ Yang Wang \\ Chinese PLA General Hospital \\ yan rong Luo \\ Chinese PLA General Hospital \\ Lin Ma \\ Chinese PLA General Hospital \\ shi ming Yang \\ Chinese PLA General Hospital \\ xin xin Zhang ( $\square$ xinxinzhang66@hotmail.com) \\ Chinese PLA General Hospital
}

\section{Research article}

Keywords: carotid invasion, locally advanced nasopharyngeal carcinoma, helical tomography, induction chemotherapy, EGFR inhibitor, neck hemorrhage

Posted Date: December 1st, 2020

DOI: https://doi.org/10.21203/rs.3.rs-115813/v1

License: @ (i) This work is licensed under a Creative Commons Attribution 4.0 International License. Read Full License 


\section{Abstract}

\section{Purpose:}

Locally advanced nasopharyngeal carcinoma (LANC) often invades the parapharyngeal space and internal carotid artery. Patients with LANC and carotid artery invasion have a poor prognosis, which often result from massive neck hemorrhage after radiotherapy.

We examined risk factors potentially influencing the therapeutic effects of radiotherapy in LANC patients with carotid artery invasion and the risk of massive neck hemorrhage.

\section{Methods:}

This retrospective study included 130 LANC patients with carotid artery invasion admitted to our hospital between January 2012 and September 2019. All patients were treated with induction chemotherapy followed by concurrent chemoradiotherapy \pm epidermal growth factor receptor (EGFR) inhibitor. Effects of clinical factors and treatment regimens on prognosis were evaluated.

\section{Outcomes:}

The 5-year progression-free survival (PFS), distant metastasis-free survival (DMFS), local nodal recurrence-free survival (LNRFS), local recurrence-free survival (LRFS), nodal recurrence-free survival (NRFS) and overall survival (OS) of the 130 patients were $75.2 \%, 76.8 \%, 90.0 \%, 93.9 \%, 95.8 \%, 87.2 \%$, respectively. The incidence of fatal bleeding after radiotherapy was $2.3 \%(3 / 130)$. For these 3 cases, the degree of carotid artery invasion was $\geq 270^{\circ}$, the primary site was the pharyngeal recess and the patients suffered nasopharyngeal necrosis after radiotherapy.Univariate analysis showed that clinical stage was negatively correlated with DMFS and PFS $(\mathrm{P}<0.05)$. The induction chemotherapy TP regimen, platinum-based concurrent chemotherapy and EGFR inhibitors (Nituzumab/Cetuximab) significantly improved PFS and DMFS $(P<0.05)$. Patients with hemoglobin levels $>110 \mathrm{~g} / \mathrm{L}$ had a higher PFS, DMFS and OS than patients with hemoglobin levels $\leq 110 \mathrm{~g} / \mathrm{L}(\mathrm{P}<0.05)$. Multivariate analysis showed that the EGFR inhibitor was an independent risk factor for PFS and DMFS, while the lowest hemoglobin level was an independent risk factor for OS.

\section{Conclusion:}

In LANC patients whose carotid artery invasion was $<270^{\circ}$, helical tomotherapy combined with concurrent chemotherapy and EGFR inhibitor after induction chemotherapy had mild and tolerable side effects, better PFS and DMFS, and did not cause massive hemorrhage. In patients whose primary tumor was pharyngeal recess with carotid artery invasion $\geq 270^{\circ}$, diabetes or reradiotherapy led to a higher risk of massive hemorrhage after radiotherapy.

\section{Background}

Nasopharyngeal carcinoma (NPC) is a malignant neoplasm with high radiosensitivity that has a unique etiology and geographic distribution. Due to the special anatomical location of the tumor, approximately $70 \%$ of newly diagnosed NPC cases are classified as locoregionally advanced disease. NPC lesions often infiltrate the surrounding area, which includes the internal carotid artery. Concurrent chemoradiotherapy (CCRT), with or without epidermal growth factor receptor (EGFR) inhibitors, has become the standard treatment for locally advanced nasopharyngeal carcinoma (LANC) [1-3].

Radiotherapy may successfully treat tumor tissue, but may damage the carotid artery, leading to fatal hemorrhage in certain patients. No relevant studies have reported the therapeutic effects and associated risk factors for fatal massive hemorrhage in patients with LANC accompanied by carotid artery invasion. This retrospective study analyzed the therapeutic effects and associated risk factors in 130 LANC patients with carotid artery invasion.

\section{Methods}


This retrospective study enrolled 130 LANC patients (male 98, female 32; age range 10 to 74 years, mean age 48 years) with carotid artery invasion admitted to our hospital between January 2012 and September 2019. All patients had histologically proven stage III-IVA squamous cell carcinoma, largely non-keratinizing type, according to the most recent edition of the American Joint Committee on Cancer (AJCC) tumor/node/metastasis (TNM) classifications and prognostic stage groups (Table 1) [4]. To rule out synchronous primary cancers and metastatic disease, all patients were fully evaluated using positron emission tomography-computed tomography (PET-CT) or magnetic resonance imaging (MRI) of the head and neck, fabric nasopharyngoscopy, chest CT, abdominal ultrasound, and bone scans. Patients with synchronous primary cancers and/or metastatic disease were excluded. All patients had an Eastern Cooperative Oncology Group (ECOG) performance status of 0 or 1 [5], and adequate renal, hepatic, and bone marrow functions before chemoradiotherapy.

\section{Treatments}

\section{Chemotherapy and EGFR inhibitor therapy}

All patients received 2-4 cycles of induction chemotherapy followed by concurrent chemoradiotherapy. EGFR-positive patients received either Cetuximab or Nimotuzumab, while EGFR-negative patients received Cetuximab (Table 2). All patients received oral mucositis prophylaxis followed by conventional mucositis treatment combined with quinolone antibiotics [6].

\section{Radiotherapy}

Helical tomotherapy (HT) was delivered once daily, 5 days per week, as previously described [7]. In brief, the planning dose at D95 (dose received by $95 \%$ of the target volume) was set at 67.5 grays (Gy) for the planning gross target volume of the primary tumor (pGTVnx) and the planning gross target volume of the metastatic lymph node (pGTVnd). The planning target volume (PTV) was set at $60 \mathrm{~Gy}$ and the PTV2 was set at $54 \mathrm{~Gy}$ in 30-33 fractions. No more than $5 \%$ of PTV volume received more than $110 \%$ of the prescribed dose. Dose-volume constraints for organs at risk (OARs) were set as follows: (1) parotid gland V $30<50 \%$

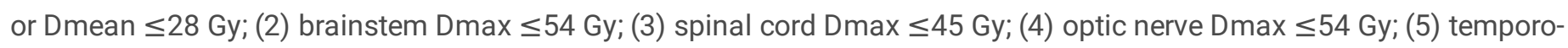
mandibular joint Dmax $\leq 60 \mathrm{~Gy}$; and (6) lens Dmax $\leq 5 \mathrm{~Gy}$. HT plans were developed for a field width of $2.5 \mathrm{~cm}$, a pitch of $0.30-$ 0.38 , and a modulation factor equal to 2.0-3.0. During radiation therapy, patients underwent megavoltage computed tomography (MVCT) imaging at least once each week to verify patient setup. The imaging frequency was determined by the magnitude of setup errors from initial daily scans.

\section{Dose modifications}

The cetuximab dose was reduced if a patient experienced an uncontrollable and persistent grade 2 acne-like rash. Chemotherapy doses and regimens were adjusted based on the severity of myelosuppression, hepatic and renal function, and drug sensitivity. For example, carboplatin was administered instead of cisplatin if grade 1 renal toxicity was caused by cisplatin.

\section{Radiographic evaluation}

Axial scans of the neck obtained using contrast-enhanced MRI were reviewed by a radiologist. The circumference of tumor attachment to the artery and the disappearance of fat gaps were utilized to estimate the extent of carotid artery invasion [8], which was classified into three subtypes according to the involvement grade (IG) (Fig. 1-A-C) as follows:

(1) Low involvement: the tumor invaded and/or contacted less than $180^{\circ}$ of the carotid artery.

(2) Mid-involvement: the tumor invaded and/or contacted more than $180^{\circ}$ but less than $270^{\circ}$ of the carotid artery.

(3) High involvement: the tumor invaded and/or contacted more than $270^{\circ}$ of the carotid artery.

(Fig. 1-A-C)

Location maps before(Fig.1-D) and after(Fig.1-d) induction chemotherapy 
Figure 1. (A) T1WI-C MRI of the right-sided nasopharyngeal carcinoma before therapy, showing extensive involvement of the right prevertebral and pterygoid muscles with less than $180^{\circ}$ encasement of the right ICA. (B) T1WI-C MRI of the left-sided nasopharyngeal carcinoma before therapy, showing extensive involvement of the left prevertebral and pterygoid muscles with more than $180^{\circ}$ but less than $270^{\circ}$ encasement of the left ICA. (C) T1WI-C MRI of the bilateral-sided nasopharyngeal carcinoma before therapy, showing extensive involvement of the bilateral prevertebral and the pterygoid muscles with more than $270^{\circ}$ encasement of the bilateral ICA.

Gaps between the tumor and carotid artery were wider after two induction chemotherapy treatments compared with the gaps before treatment (Fig.1-D-d).

Notes: Arrowheads indicate the ICA; Abbreviations: MRI, magnetic resonance imaging; ICA, internal carotid artery; T1WI, T1weighted imaging.

\section{Follow up}

Follow-up examinations were scheduled with patients according the following schedule: every 3 months in the first year, every 4 months in the second and third year, every 6 months in the fourth and fifth years and then yearly until recurrence or death. Four patients were lost to follow-up. Endpoints for this clinical trial were similar to those in our previous study [9]. Acute and late toxicities observed in patients following treatment were graded according to the National Cancer Institute-Common Terminology Criteria for Adverse Events (CTCAE), version 5.0, and the Radiation Therapy Oncology Group (RTOG) Late Radiation Morbidity Scoring Criteria [10], respectively.

\section{Statistical Analysis}

Data were analyzed using SPSS 24.0 statistical software (IBM Corporation, Armonk, NY, USA). 95\% confidence intervals (Cls) were calculated for means and percentages. Curves of PFS, DMFS, LNRFS, LRFS, NRF and OS were estimated with the KaplanMeier method (GraphPad Prism 8.0.1). Group frequency data were examined using Chi-squared tests. Multivariate Cox regression analyses were used for survival correlation factors, and log-rank tests were used for inter-group curve comparisons.

\section{Results}

In the present study, 140 consecutive patients were screened for eligibility and 130 patients were enrolled in the clinical trail. Ten patients were excluded ( 4 were lost to follow-up and 6 were unable to tolerate side effects during concurrent chemoradiotherapy). Patients were stratified into 3 groups based on the degree of carotid artery involvement: $<180^{\circ}, n=37$; $180^{\circ} \leq \mathrm{IG}<270^{\circ}, \mathrm{n}=32$; and $\geq 270^{\circ}, \mathrm{n}=61$.

Three patients whose primary tumor was located in the nasopharyngeal recess and had carotid artery invasion $\geq 270^{\circ}$ died of massive neck hemorrhage (Table 3;Fig.2).

The median follow-up time was 25 months (range 5-97 months).During follow-up, 20 patients died, including 13 cancer-related deaths and 7 non-cancer-related deaths. Twenty-two patients experienced disease progression, including 3 patients with recurrence, 2 with cervical lymph node metastasis, 16 with distant metastasis, and 1 with secondary primary cancer.The overall 5-year survival rates were PFS=75.2\%, DMFS=76.8\%, LNRFS=90.0\%, LRFS=93.9\%, NRFS=95.8\% and OS=87.2\%(Fig.3).

Univariate analysis showed that gender, age, pathological type, and degree of carotid artery involvement were not significantly associated with survival. Clinical stage, induction chemotherapy regimen, concurrent chemotherapy regimen, and EGFR inhibitors were significantly associated with PFS and DMFS $(P<0.05)$. Hemoglobin levels during radiotherapy were significantly associated with DMFS, PFS, and OS ( $P<0.05)$ (Table 4,see Appendix).

Multivariate analysis showed that EGFR inhibitor was an independent prognostic factor for DMFS and PFS $(P<0.05)$. Hemoglobin level during radiotherapy was an independent prognostic factor for OS $(P<0.05)$ (Table 5;Fig4-6). 
Comparison of three degrees of the carotid artery invasion $\left(<180^{\circ}, 180^{\circ} \leq \mathrm{IG}<270^{\circ}, \geq 270^{\circ}\right)$ suggests that the 5-year PFS was $82.3 \%, 72.4 \%$, and $59.5 \%$, respectively; 5 -year DMFS was $85.8 \%, 78.0 \%$, and $77.1 \%$, respectively; 5 -year LNRFS was $95.8 \%, 90.4 \%$, and $77.1 \%$, respectively; 5 -year LRFS was $95.8 \%, 100 \%$, and $77.1 \%$, respectively; 5 -year NRFS was $100 \%$, $90.4 \%$, and $100 \%$, respectively; and 5-year OS was $92.9 \%, 85.2 \%$, and 78.0\%, respectively(Fig.7-12).

\section{Acute toxicities}

All possible side effects were documented for each patient. Acute toxic effects were very mild and did not reach grade 4 . The most common grade 1-2 toxicities included oropharyngeal mucositis, RT-related dermatitis, xerostomia, and pharyngoesophagitis, which were less severe than those of intensity-modulated radiation therapy (IMRT) (Table 6). Acute toxicities 1 month after radiotherapy were significantly improved compared to those observed at the conclusion of radiotherapy. Some patients treated with concurrent chemotherapy or EGFR inhibitors showed different degrees of bone marrow toxicity. After full radiotherapy, patient weight loss varied from _0_\% to _20.4_\%; average weight loss was 10.6\%.

\section{Discussion}

In this study, 130 LANC patients with carotid artery invasion were treated with induction chemotherapy followed by concurrent chemoradiotherapy \pm an EGFR inhibitor. Five-year survival rates were: PFS=75.2\%; DMFS=76.8\%; LNRFS=90.0\%; LRFS=93.9\%; NRFS $=95.8 \%$ and $O S=87.2 \%$. Side effects were mild and well-tolerated; survival rates were similar to those observed in other studies [11-15].

Accoring to our comparison of the survival rates in patients with three degrees of carotid artery invasion $\left(<180^{\circ}, 180^{\circ} \leq \mathrm{G}<270^{\circ}\right.$, and $\left.\geq 270^{\circ}\right)$, although the survival rate difference was not statistically significant, the study showed that the survival rate tended to decrease with a greater degree of invasion. According to the National Comprehensive Cancer Network (NCCN) [16], carotid artery invasion is a sign of poor prognosis; however, compared with other head and neck tumors, patients with LANC with carotid artery invasion have a better prognosis.

Among the 32 cases with carotid artery invasion $<180^{\circ}$ and the 37 cases with $180^{\circ} \leq 1 \mathrm{G}<270^{\circ}$, no patients suffered fatal neck hemorrhage. Three of the 61 patients with carotid artery invasion $\geq 270^{\circ}$ died of neck hemorrhage; the overall incidence was $2.3 \%(3 / 130)$. Ling et al. [17] found that $1.5 \%$ of nasopharyngeal carcinoma patients with IMRT experienced fatal bleeding. In our study, fatal massive neck hemorrhage was attributable to nasopharyngeal necrosis in all the 3 patients, 2 of which were diabetic and 1 received re-radiation after recurrence. Most scholars believe that radiation, trauma and infection cause nasopharyngeal necrosis [18]. The 2 diabetic patients had uncontrollable infection with local necrosis. The patient who received re-radiation was exposed to a cumulative radiation dose of $137.5 \mathrm{~Gy}$ and developed osteoradionecrosis of the nasopharynx seven months after radiotherapy. This patient died of fatal hemorrhage 2 months later. Re-radiation increases the risk of necrosis of the nasopharynx and neck hemorrhage [19].

Yousem et al. [20] predicted using MRI images that patients with tumor surrounding the carotid artery $\geq 270^{\circ}$ are at significantly increased risk of artery invasion. Other studies have shown that patients whose primary tumor was located in the pharyngeal recess, and who experienced inflammation and an opening incisor tooth distance $<1 \mathrm{~cm}$, had a greater probability of fatal bleeding after radiotherapy [21]. Similarly, the 3 patients with fatal hemorrhage in this study all had a pharyngeal recess with a restricted opening. Yamazaki et al. [18] and Cheng et al. [22] believed that the pharyngeal recess is part of the petrosal region of the internal carotid artery where the tumor easily invades the internal carotid artery and surrounding bone. If the pharyngeal recess becomes infected, the surrounding tissues may become necrotic, which may cause rupture of the internal carotid artery and fatal bleeding.

In this study, 127 patients without massive hemorrhage benefited from the application of induction/concurrent chemotherapy and HT. Induction chemotherapy may reduce tumor load, enlarge the space between the carotid artery and the tumor body and produce a greater safety margin, thereby reducing damage to important tissues and organs caused by radiotherapy. Dionisi et al. [23] showed that concurrent chemotherapy could further shrink the tumor body, accelerate blood supply to surrounding tissues, and reduce the incidence of mucosal necrosis. HT has many dosimetric advantages, such as delivering a more precise 
dosage to the target tissue(s) and reducing radiation exposure to critical surrounding organs, thereby improving local control with less radiation damage [24].

In this study, we found that the 5-year OS of patients with the lowest hemoglobin levels $(\leq 110 \mathrm{~g} / \mathrm{L})$ was significantly lower than that of patients with hemoglobin levels $>110 \mathrm{~g} / \mathrm{L}$ during radiotherapy. Brizel et al. [25] showed that anemia is closely related to tumor hypoxia, which may lead to tumor resistance to radiotherapy and treatment failure. Therefore, we believe that patients should actively monitor and treat anemia. In addition, multivariate analysis showed that use of an EGFR inhibitor was an independent prognostic factor for PFS and DMFS. Previous studies have shown that adding CTX/NTZ to CCRT may improve OS, DFS and DMFS [26-30], which is consistent with our results. EGFR inhibitors also have been shown to have significant antiproliferation, pro-apoptosis and anti-angiogenesis effects, which may further control the recurrence of tumors and improve the sensitivity of tumors to radiotherapy and chemotherapy [31].

In conclusion, $95.7 \%$ of the patients diagnosed with LANC and carotid artery invasion, who were treated by induction chemotherapy followed by concurrent chemoradiotherapy \pm EGFR inhibitors at our institution, successfully completed the entire treatment regimen [7]. Patients whose primary carcinoma was located in the pharyngeal recess and surrounded the carotid artery by $\geq 270^{\circ}$, especially diabetic patients, should actively control blood glucose levels and schedule regular appointments with their physician. Patients with necrosis of the nasopharynx should be actively examined by nasal endoscope and prescribed antibiotics and hyperbaric treatments. In addition, surgery may be a better option than re-radiation for patients with carotid artery invasion $\geq 270^{\circ}$ who experience recurrence.

In this study, 130 patients with LANC surrounding the carotid artery were treated with a comprehensive treatment regimen that produced desirable outcomes and a low incidence of fatal hemorrhage. Improved outcomes may be possible with the application of new proton and other radiotherapy technologies and new PD-1 immuno-targeted drugs in patients with nasopharyngeal carcinoma.

\section{Abbreviations}

LANC,Locally advanced nasopharyngeal carcinoma; MRI, magnetic resonance imaging; ICA, internal carotid artery; T1WI, T1weighted imaging

EGFR,epidermal growth factor receptor inhibitor; PFS,progression-free survival; DMFS, distant metastasis-free survival; LNRFS,local nodal recurrence-free survival; LRFS,local recurrence-free survival; NRFS, nodal recurrence-free survival ; OS,overall survival

T: docetaxel; P: cisplatin; F: 5-fluorouracil; G: Gemcitabine; D: Doxorubicin

HR3,Nimotuzumab; C-225,Cetuximab; HT,helical tomography

\section{Declarations}

\section{Acknowledgements}

We appreciate the linguistic assistance provided by TopEdit (www.topeditsci.com) during the preparation of this manuscript.

\section{Competing interests}

The authors declare that they have no competing interests

\section{Funding}

No funding was received.

\section{Availability of data and materials}

The datasets used and/or analyzed during the present study are available from the corresponding author on reasonable request.

\section{Authors' contributions}

Page 6/20 
$\mathrm{KL}, \mathrm{SY}$ and $\mathrm{XZ}$ contributed to the conception of this study and performed the preliminary documentation. All authors participated in the design of the study and implemented the research.

$\mathrm{KL}$, JW and LM examined the archives and identified the cases included in the study, examined the slides and collected the pathological information. $\mathrm{KL}, \mathrm{QW}, \mathrm{YW}$, and $\mathrm{YL}$ enrolled patients in

the study, performed clinical diagnosis and collected clinical data. All authors participated in the statistical analysis and contributed to the interpretation of the results, as well as the writing of the study. All authors reviewed the data and approved the final manuscript.

\section{Ethics approval and consent to participate}

This research abides by international and national regulations in accordance with the Declaration of Helsinki. This study was approved by the Ethics Committee of the Chinese PLA General Hospital. All patients provided written informed consent before being included in this study (patients under 16 years old were obtained from a parent or guardian for participants)

\section{Patient consent for publication}

Not applicable.

\section{References}

1. Chen YP, Chan ATC, Le QT, et al. Nasopharyngeal carcinoma. Lancet. 2019;394(10192):64-80.

2. Chua MLK, Wee JTS, Hui EP, Chan ATC. Nasopharyngeal carcinoma. Lancet. 2016;387(10022):1012-24.

3. Li Y, Xu T, Qian W, et al. Radiation-induced nasopharyngeal ulcers after intensity modulated radiotherapy in primary nasopharyngeal carcinoma patients: a dose-volume-outcome analysis. Oral Oncol. 2018;84:1-6.

4. Amin MB, Edge SB, Greene FL et al, editors. AJCC Cancer Staging Manual. 8th ed. New York: Springer; 2017.

5. Oken M, Creech R, Tormey D, et al. Toxicity and response criteria of the Eastern Cooperative Oncology Group. Am J Clin Oncol. 1982;5:649-55.

6. Zhang XX, Ma L, Wang JL, et al. [Management of oral mucositis in patients with head and neck cancer receiving chemoradiotherapy and/or molecular targeted therapy]. Chin J Otorhinolaryngol Head Neck Surg. 2011;46(6):505-8.

7. Du L, Zhang XX, Ma L, et al. Clinical study of nasopharyngeal carcinoma treated by helical tomotherapy in China: 5-year outcomes. Biomed Res Int. 2014; 980767.

8. Zheng L, Yan S, Yan D, et al. Fatal bleeding in a nasopharyngeal carcinoma patient after concurrent chemoradiation plus cetuximab: a case report. Onco Targets Ther. 2013;6:703-6.

9. Zhang X, Wang J, Wu W, et al. Efficacy and safety of combined radiotherapy with EGFR inhibitors and chemotherapy for laryngeal organ preservation in patients with locally advanced hypopharyngeal carcinomas. Curr Cancer Drug Targets. 2014;14(6):589-98.

10. Cox JD, Stetz J, Pajak TF. Toxicity criteria of the Radiation Therapy Oncology Group (RTOG) and the European Organization for Research and Treatment of Cancer (EORTC). Int J Radiat Oncol Biol Phys. 1995;31(5):1341-6.

11. Wang ZQ, Mei Q, Li JB, et al. The long-term survival of patients with III-IVb stage nasopharyngeal carcinoma treated with IMRT with or without Nimotuzumab: a propensity score-matched analysis. BMC Cancer. 2019;19(1):1122.

12. You R, Hua YJ, Liu YP, et al. Concurrent chemoradiotherapy with or without anti-EGFR-targeted treatment for stage II-IVb nasopharyngeal carcinoma: retrospective analysis with a large cohort and long follow-up. Theranostics. 2017;7(8):231424.

13. Xia WX, Liang H, Xing L, et al. Stage-specific concurrent chemoradiotherapy with or without induction chemotherapy for locoregionally advanced nasopharyngeal carcinoma: a retrospective, population-based study. Cancer Manag Res. 2019;11:9813-27.

14. Slevin F, Pan S, Mistry H, et al. A multicentre UK study of outcomes of nasopharyngeal carcinoma treated with intensitymodulated radiotherapy \pm chemotherapy. Clin Oncol (R Coll Radiol). 2020;32(4):238-49.

15. Wu F, Wu LL, Chen GF, et al. [Retrospective study on the efficacy of different chemotherapy regimens concurrently combined with intensity modulated radiation therapy in treatment of III-IVa stage nasopharyngeal carcinoma]. Journal of Clinical 
Otorhinolaryngology. 2016;30(19):1536-9.

16. Colevas AD, Yom SS, Pfister DG, et al. NCCN guidelines insights: head and neck cancers, version 1.2018. J Natl Compr Canc Netw. 2018;16(5):479-90.

17. Zheng LY, Yan SX, Yan DF, et al. Fatal bleeding in a nasopharyngeal carcinoma patient after concurrent chemoradiation plus cetuximab: a case report. Onco Targets Ther. 2013;6:703-6.

18. Yamazaki H, Ogita M, Himei K, et al. Carotid blowout syndrome in pharyngeal cancer patients treated by hypofractionated stereotactic re-irradiation using CyberKnife: a multi-institutional matched-cohort analysis. Radiother Oncol. 2015;115(1):67-71.

19. Teo PM, Leung SF, Lee WY, et al. Intracavitary brachytherapy significantly enhances local control of early T-stage nasopharyngeal carcinoma: the existence of a dose-tumor-control relationship above conventional tumoricidal dose. Int $\mathrm{J}$ Radiat Oncol Biol Phys. 2000;46(2):445-58.

20. Yousem DM, Hatabu H, Hurst RW, et al. Carotid artery invasion by head and neck masses: prediction with MR imaging. Radiology. 1995;195(3):715-20.

21. Wu RK, Chen ZQ, Chen YL, et al. Risk factors, signs and prevention of massive bleeding in patients with nasopharyngeal carcinoma after radiotherapy. Intern Med. 2017;12(3):392-4..(in China).

22. Cheng KY, Lee KW, Chiang FY, et al. Rupture of radiation-induced internal carotid artery pseudoaneurysm in a patient with nasopharyngeal carcinoma-spontaneous occlusion of carotid artery due to long-term embolizing performance. Head Neck. 2008;30(8):1132-5.

23. Dionisi F, Fiorica F, D'Angelo E, et al. Organs at risk's tolerance and dose limits for head and neck cancer re-irradiation: a literature review. Oral Oncol. 2019;98:35-47.

24. Du L, Zhang XX, Feng LC, et al. Treatment of nasopharyngeal carcinoma using simultaneous modulated accelerated radiation therapy via helical tomotherapy: a phase II study. Radiol Oncol. 2016;50(2):218-25.

25. Shen C, Lu JJ, Gu Y, et al. Prognostic impact of primary tumor volume in patients with nasopharyngeal carcinoma treated by definitive radiation therapy. Laryngoscope. 2008;118(7):1206-10.

26. Liu WS, Hsin $\mathrm{CH}$, Chou YH, et al. Long-term results of intensity-modulated radiotherapy concomitant with chemotherapy for hypopharyngeal carcinoma aimed at laryngeal preservation. BMC Cancer. 2010;10:102.

27. Bonner JA, Harari PM, Giralt J, et al. Radiotherapy plus cetuximab for squamous-cell carcinoma of the head and neck. $N$ Engl J Med. 2006;354(6):567-78.

28. Bonner JA, Harari PM, Giralt J, et al. Radiotherapy plus cetuximab for locoregionally advanced head and neck cancer: 5-year survival data from a phase 3 randomised trial, and relation between cetuximab-induced rash and survival. Lancet Oncol. 2010;11(1):21-8.

29. Caudell JJ, Sawrie SM, Spencer SA, et al. Locoregionally advanced head and neck cancer treated with primary radiotherapy: a comparison of the addition of cetuximab or chemotherapy and the impact of protocol treatment. Int J Radiat Oncol Biol Phys. 2008;71(3):676-81.

30. Ramakrishnan MS, Eswaraiah A, Crombet T, et al. Nimotuzumab, a promising therapeutic monoclonal for treatment of tumors of epithelial origin. MAbs. 2009;1(1):41-8.

31. Diaz Miqueli A, Rolff J, Lemm M, et al. Radiosensitisation of U87MG brain tumours by anti-epidermal growth factor receptor monoclonal antibodies. Br J Cancer. 2009;100(6):950-8.

\section{Tables}

\section{Table 1. Patient characteristics}




\begin{tabular}{|c|c|}
\hline Characteristics & Patients (n, \%) \\
\hline \multicolumn{2}{|l|}{ Age } \\
\hline$<60$ years & $100(76.9)$ \\
\hline$\geq 60$ years & $30(23.1)$ \\
\hline \multicolumn{2}{|l|}{ Gender } \\
\hline Male & $98(75.4)$ \\
\hline Female & $32(24.6)$ \\
\hline \multicolumn{2}{|l|}{ ECOG performance status } \\
\hline 0 & $80(61.5)$ \\
\hline 1 & $50(38.5)$ \\
\hline \multicolumn{2}{|l|}{ Pathology } \\
\hline WHO type I & $7(5.4)$ \\
\hline WHO type II & $123(94.6)$ \\
\hline \multicolumn{2}{|l|}{ Tumor site } \\
\hline Nasopharyngeal recess & $81(62.3)$ \\
\hline Nasopharyngeal posterior wall & $36(27.7)$ \\
\hline Nasopharyngeal lateral wall & $11(8.5)$ \\
\hline Submucosal nasopharyngeal cancer & $2(1.5)$ \\
\hline \multicolumn{2}{|l|}{ AJCC $8^{\text {th }}$ stage } \\
\hline III & $52(40.0)$ \\
\hline IVA & $78(60.0)$ \\
\hline \multicolumn{2}{|l|}{ T stage } \\
\hline $\mathrm{T} 2$ & $19(14.6)$ \\
\hline T3 & $63(48.5)$ \\
\hline $\mathrm{T} 4$ & $48(36.9)$ \\
\hline \multicolumn{2}{|l|}{ N stage } \\
\hline NO & $13(10.0)$ \\
\hline N1 & $14(10.8)$ \\
\hline N2 & $63(48.5)$ \\
\hline N3 & $40(30.7)$ \\
\hline \multicolumn{2}{|l|}{ Involvement grade } \\
\hline$<180^{\circ}$ & $32(24.6)$ \\
\hline $180^{\circ} \leq \mathrm{IG}<270^{\circ}$ & $37(28.5)$ \\
\hline$\geq 270^{\circ}$ & $61(46.9)$ \\
\hline Minimum hemoglobin during radiothe & \\
\hline
\end{tabular}

Page 9/20 


\begin{tabular}{|ll|}
$\leq 110 \mathrm{~g} / \mathrm{L}$ & $91(70.0)$ \\
\hline$>110 \mathrm{~g} / \mathrm{L}$ & $39(30.0)$ \\
\hline
\end{tabular}

Table 2. Chemotherapy regimens

\begin{tabular}{|c|c|c|c|}
\hline Stage & Regimen & Dose & No. of cases \\
\hline \multirow[t]{6}{*}{ ICT } & TP & $\mathrm{T}: 70 \mathrm{mg} / \mathrm{m}^{2}$ & 102 \\
\hline & & $P: 40 \mathrm{mg} / \mathrm{m}^{2}$ & \\
\hline & TPF/TP+TS-1 & $\mathrm{T}: 70 \mathrm{mg} / \mathrm{m}^{2}$ & 28 \\
\hline & & $\mathrm{P}: 70 \mathrm{mg} / \mathrm{m}^{2}$ & \\
\hline & & $\mathrm{F}: 700 \mathrm{mg} / \mathrm{m}^{2}$ & \\
\hline & & TS-1: 40 60 mg, twice a day & \\
\hline \multirow[t]{6}{*}{ CCRT } & TP & $\mathrm{T}: 70 \mathrm{mg} / \mathrm{m}^{2}$ & 19 \\
\hline & & $\mathrm{P}: 40 \mathrm{mg} / \mathrm{m}^{2}$ & \\
\hline & $\mathrm{P} / \mathrm{N}$ & $P: 40 \mathrm{mg} / \mathrm{m}^{2}$ & 42 \\
\hline & $\mathrm{T}$ & $\mathrm{T}: 70 \mathrm{mg} / \mathrm{m}^{2}$ & 55 \\
\hline & $G+D$ & $\mathrm{G}: 1000 \mathrm{mg} / \mathrm{m}^{2}$ & 12 \\
\hline & Others & TPF or TS-1 & 2 \\
\hline \multirow[t]{2}{*}{ EGFR inhibitor } & Nimotuzumab, HR3 & $200 \mathrm{mg} / \mathrm{m}^{2}$ weekly for 7 weeks & 95 \\
\hline & Cetuximab, C-225 & $250 \mathrm{mg} / \mathrm{m}^{2}$ weekly (400 mg/m² initial dose) for 7 weeks & 4 \\
\hline
\end{tabular}

T: docetaxel; P: cisplatin; F: 5-fluorouracil; G: Gemcitabine; D: Doxorubicin

Table 3. Characteristics of the three patients with massive neck hemorrhage

\begin{tabular}{|lllllll|}
\hline No. & $\begin{array}{l}\text { Re- } \\
\text { irradiation }\end{array}$ & RT dose & ICT/CCRT & $\begin{array}{l}\text { EGFR } \\
\text { inhibitor }\end{array}$ & $\begin{array}{l}\text { Clinical } \\
\text { sasopharyngeal } \\
\text { stage } \\
\text { features under } \\
\text { endoscope and } \\
\text { MRI(Fig.2) }\end{array}$ \\
\hline 1 & No & $67.5 \mathrm{~Gy} / 30 \mathrm{~F}$ & TP/TP & HR3 & III & MN \\
\hline 2 & No & $67.5 \mathrm{~Gy} / 30 \mathrm{~F}$ & TP+TS-1/P & HR3 & IVA & MN \\
\hline 3 & Yes & $\begin{array}{l}67.5 \mathrm{~Gy} / 30 \mathrm{~F}+70 \\
\text { Gy/35 F }\end{array}$ & $\begin{array}{l}\text { PT/P冈two cycles of lobaplatin } \\
\text { after recurrence }\end{array}$ & None & IVA & OR and MN \\
\hline
\end{tabular}




\begin{tabular}{|c|c|c|c|c|c|c|c|}
\hline No. & Age & $\begin{array}{l}\text { Difficulty in } \\
\text { opening } \\
\text { mouth }\end{array}$ & Hypertension & Diabetes & Anemia & $\begin{array}{l}\text { Time of necrosis after } \\
\text { radiotherapy(months) }\end{array}$ & $\begin{array}{l}\text { Time } \\
\text { of massive } \\
\text { hemorrhage } \\
\text { after } \\
\text { radiotherapy(months) }\end{array}$ \\
\hline 1 & 54 & Yes & No & Yes & $\begin{array}{l}101 \\
\mathrm{~g} / \mathrm{L}\end{array}$ & 10 & 12 \\
\hline 2 & 63 & Yes & No & Yes & $\begin{array}{l}101 \\
g / L\end{array}$ & 9 & 12 \\
\hline 3 & 55 & No & Yes & No & $97 \mathrm{~g} / \mathrm{L}$ & 7 & 9 \\
\hline
\end{tabular}

Abbreviations: OR, osteoradionecrosis; MN, membrane necrosis; Nimotuzumab, HR3

Table 4. Kaplan-meier analysis of risk factors and patient prognosis 


\begin{tabular}{|c|c|c|c|c|c|c|c|c|c|c|}
\hline Risk factor & Cases & $\begin{array}{l}\text { Deaths } \\
\text { (all) }\end{array}$ & $\begin{array}{l}\text { Deaths } \\
\text { (tumor- } \\
\text { related) }\end{array}$ & $\begin{array}{l}\text { 5-year } \\
\text { OS } \\
\text { (tumor- } \\
\text { related) }\end{array}$ & $\begin{array}{l}95 \% \\
\mathrm{Cl} \\
\text { (OS) }\end{array}$ & P (OS) & $\begin{array}{l}95 \% \\
\mathrm{Cl} \\
\text { (PFS) }\end{array}$ & $\begin{array}{l}\text { Disease } \\
\text { Progression }\end{array}$ & $\begin{array}{l}\text { 5-year } \\
\text { PFS }\end{array}$ & P (PFS) \\
\hline \multicolumn{11}{|l|}{ Age (years) } \\
\hline$<60$ & 100 & 15 & 11 & $87.2 \%$ & $\begin{array}{l}0.19- \\
4.39\end{array}$ & \multirow[t]{2}{*}{0.903} & $\begin{array}{l}68.00- \\
83.89\end{array}$ & 20 & $70.3 \%$ & \multirow[t]{2}{*}{0.307} \\
\hline$\geq 60$ & 30 & 5 & 2 & $89.3 \%$ & $\begin{array}{l}0.23 \\
-5.34\end{array}$ & & $\begin{array}{l}77.59- \\
97.50\end{array}$ & 2 & $91.1 \%$ & \\
\hline \multicolumn{11}{|l|}{ Gender } \\
\hline Male & 98 & 15 & 9 & $88.2 \%$ & $\begin{array}{l}24.39- \\
47.57\end{array}$ & 0.508 & $\begin{array}{l}22.44- \\
46.50\end{array}$ & 17 & $81.0 \%$ & 0.551 \\
\hline Female & 32 & 5 & 4 & $84.5 \%$ & $\begin{array}{l}28.72- \\
54.29\end{array}$ & & $\begin{array}{l}29.01- \\
55.58\end{array}$ & 5 & $86.7 \%$ & \\
\hline \multicolumn{11}{|l|}{ Tumor site } \\
\hline $\begin{array}{l}\text { Nasopharyngeal } \\
\text { recess }\end{array}$ & 81 & 18 & 12 & $81.0 \%$ & $\begin{array}{l}5.29- \\
35.57\end{array}$ & \multirow[t]{4}{*}{0.159} & $\begin{array}{l}5.39- \\
31.18\end{array}$ & 16 & $64.5 \%$ & \multirow[t]{4}{*}{0.607} \\
\hline $\begin{array}{l}\text { Nasopharyngeal } \\
\text { posterior wall }\end{array}$ & 36 & 2 & 1 & $96.0 \%$ & $\begin{array}{l}22.24- \\
43.23\end{array}$ & & $\begin{array}{l}19.56- \\
41.81\end{array}$ & 5 & $74.1 \%$ & \\
\hline $\begin{array}{l}\text { Nasopharyngeal } \\
\text { lateral wall }\end{array}$ & 11 & 0 & 0 & $100 \%$ & $\begin{array}{l}11.41- \\
19.24\end{array}$ & & $\begin{array}{l}10.20- \\
16.99\end{array}$ & 1 & $82.5 \%$ & \\
\hline $\begin{array}{l}\text { Submucosal } \\
\text { nasopharyngeal } \\
\text { cancer }\end{array}$ & 2 & 0 & 0 & $100 \%$ & $\begin{array}{l}39.48- \\
68.54\end{array}$ & & $\begin{array}{l}40.98- \\
69.58\end{array}$ & 0 & $100 \%$ & \\
\hline \multicolumn{11}{|l|}{ AJCC 8th stage } \\
\hline III & 52 & 9 & 4 & $88.6 \%$ & $\begin{array}{l}0.37- \\
2.15\end{array}$ & \multirow[t]{2}{*}{0.803} & $\begin{array}{l}0.18 \\
-0.97\end{array}$ & 8 & $80.4 \%$ & \multirow[t]{2}{*}{$0.042^{*}$} \\
\hline IV & 78 & 11 & 9 & $86.9 \%$ & $\begin{array}{l}0.47- \\
2.69\end{array}$ & & $\begin{array}{l}1.03- \\
5.49\end{array}$ & 14 & $59.2 \%$ & \\
\hline \multicolumn{11}{|l|}{ Pathology } \\
\hline WHO type I & 7 & 0 & 0 & $100 \%$ & $\begin{array}{l}0.22- \\
14.68\end{array}$ & \multirow[t]{2}{*}{0.125} & $\begin{array}{l}22.44- \\
46.50\end{array}$ & 1 & $80.0 \%$ & \multirow[t]{2}{*}{0.539} \\
\hline WHO type II & 123 & 20 & 13 & $86.3 \%$ & $\begin{array}{l}0.61- \\
27.56\end{array}$ & & $\begin{array}{l}29.01- \\
55.58\end{array}$ & 21 & $71.0 \%$ & \\
\hline \multicolumn{11}{|l|}{$\begin{array}{l}\text { Involvement } \\
\text { grade }\end{array}$} \\
\hline $\mathrm{IG}<180^{\circ}$ & 32 & 6 & 4 & $92.9 \%$ & $\begin{array}{l}0.37- \\
2.93\end{array}$ & \multirow[t]{3}{*}{0.622} & $\begin{array}{l}0.34- \\
2.57\end{array}$ & 4 & $82.3 \%$ & \multirow[t]{3}{*}{0.394} \\
\hline $180^{\circ} \leq \mathrm{IG}<270^{\circ}$ & 37 & 5 & 5 & $85.2 \%$ & $\begin{array}{l}0.32- \\
2.86\end{array}$ & & $\begin{array}{l}0.41- \\
3.10\end{array}$ & 7 & $70.4 \%$ & \\
\hline$I G \geq 270^{\circ}$ & 61 & 9 & 4 & $78.0 \%$ & $\begin{array}{l}0.25- \\
3.17\end{array}$ & & $\begin{array}{l}0.31- \\
3.36\end{array}$ & 11 & $59.5 \%$ & \\
\hline \multicolumn{11}{|l|}{$\begin{array}{l}\text { Minimum } \\
\text { hemoglobin } \\
\text { during } \\
\text { radiotherapy } \\
(\mathrm{g} / \mathrm{L})\end{array}$} \\
\hline$\leq 110$ & 91 & 17 & 11 & $77.3 \%$ & $1.94-$ & $0.045^{\star}$ & $1.14-$ & 18 & $57.6 \%$ & $0.028^{*}$ \\
\hline
\end{tabular}

Page 12/20 


\begin{tabular}{|c|c|c|c|c|c|c|c|c|c|c|}
\hline & & & & & 6.17 & & 6.08 & & & \\
\hline$>110$ & 39 & 3 & 2 & $94.0 \%$ & $\begin{array}{l}1.16- \\
1.96\end{array}$ & & $\begin{array}{l}0.16- \\
0.88\end{array}$ & 4 & $85.3 \%$ & \\
\hline \multicolumn{11}{|l|}{$\begin{array}{l}\text { Induction } \\
\text { chemotherapy }\end{array}$} \\
\hline $\mathrm{TP}$ & 102 & 14 & 8 & $90.1 \%$ & $\begin{array}{l}0.10 \\
-1.14\end{array}$ & \multirow[t]{2}{*}{0.082} & $\begin{array}{l}0.09- \\
0.87\end{array}$ & 15 & $74.6 \%$ & \multirow[t]{2}{*}{$0.030 \star$} \\
\hline TPF/TP+TS-1 & 28 & 6 & 5 & $70.7 \%$ & $\begin{array}{l}0.88- \\
9.68\end{array}$ & & $\begin{array}{l}1.14 \\
-11.60\end{array}$ & 7 & $40.9 \%$ & \\
\hline \multicolumn{11}{|l|}{$\begin{array}{l}\text { Concurrent } \\
\text { chemotherapy }\end{array}$} \\
\hline PT & 19 & 8 & 6 & $78.0 \%$ & $\begin{array}{l}0.10- \\
6.33\end{array}$ & \multirow[t]{5}{*}{0.122} & $\begin{array}{l}1.06- \\
4.05\end{array}$ & 5 & $71.1 \%$ & \multirow[t]{5}{*}{$0.0038^{\star}$} \\
\hline $\mathrm{P} / \mathrm{N}$ & 42 & 5 & 2 & $92.0 \%$ & $\begin{array}{l}0.03- \\
2.28\end{array}$ & & $\begin{array}{l}1.03- \\
2.18\end{array}$ & 5 & $82.6 \%$ & \\
\hline $\mathrm{T}$ & 55 & 6 & 4 & $82.7 \%$ & $\begin{array}{l}0.04- \\
2.97\end{array}$ & & $\begin{array}{l}1.04- \\
3.12\end{array}$ & 6 & $45.1 \%$ & \\
\hline$G+D$ & 12 & 0 & 0 & $100 \%$ & $\begin{array}{l}0.32- \\
11.08\end{array}$ & & $\begin{array}{l}1.18- \\
14.93\end{array}$ & 5 & $30.1 \%$ & \\
\hline Others & 2 & 1 & 1 & $50.0 \%$ & $\begin{array}{l}0.41- \\
21.56\end{array}$ & & $\begin{array}{l}1.48- \\
16.52\end{array}$ & 1 & $50.0 \%$ & \\
\hline \multicolumn{11}{|l|}{ EGFR inhibitor } \\
\hline HR3/ C-225 & 99 & 11 & 8 & $89.2 \%$ & $\begin{array}{l}0.31- \\
3.61\end{array}$ & \multirow[t]{2}{*}{0.919} & $\begin{array}{l}1.06- \\
1.32\end{array}$ & 10 & $84.8 \%$ & \multirow[t]{2}{*}{$0.043^{*}$} \\
\hline None & 31 & 9 & 5 & $85.9 \%$ & $\begin{array}{c}0.28 \\
-3.18\end{array}$ & & $\begin{array}{l}1.06- \\
1.10\end{array}$ & 12 & $60.5 \%$ & \\
\hline
\end{tabular}

Table 5. Cox multivariate regression analysis of prognostic factors

\begin{tabular}{|llllllll|}
\hline Variate & Index & B & SE & Wald & P-value & $\mathrm{HR}$ & $95 \% \mathrm{Cl}$ \\
\hline Minimum hemoglobin during radiotherapy & OS & 1.871 & 0.829 & 5.091 & $0.024^{\star}$ & 6.493 & $1.279-32.979$ \\
\hline EGFR inhibitor & PFS & 1.022 & 0.496 & 4.252 & $0.039^{\star}$ & 2.778 & $1.052-7.338$ \\
\hline EGFR inhibitor & DMFS & 1.272 & 0.574 & 4.903 & $0.027^{*}$ & 3.567 & $1.157-10.997$ \\
\hline
\end{tabular}

Abbreviations: B Beta, SE Standard Error,Cl confidence interval, HR hazard ratio, ${ }^{\star} \mathrm{P}<0.05$.

Table 6. Acute toxicity of tomotherapy (n, \%) 


\begin{tabular}{|lllll|}
\hline Toxicity & Grade 0 & Grade 1 & Grade 2 & Grade 3 \\
\hline Skin & $5(3.8 \%)$ & $98(75.4 \%)$ & $23(17.7 \%)$ & $4(3.1 \%)$ \\
\hline Mucositis & $0(0 \%)$ & $40(31.0 \%)$ & $75(57.7 \%)$ & $15(11.3 \%)$ \\
\hline Xerostomia & $4(3.1 \%)$ & $64(49.2 \%)$ & $59(45.4 \%)$ & $3(2.3 \%)$ \\
\hline Larynx & $66(50.8 \%)$ & $55(42.3 \%)$ & $9(6.9 \%)$ & $0(0 \%)$ \\
\hline Pharyngo-esophagitis & $9(6.9 \%)$ & $58(44.6 \%)$ & $60(46.2 \%)$ & $3(2.3 \%)$ \\
\hline
\end{tabular}

Table 7 Characteristics of patients with recurrence but without massive neck bleeding

\begin{tabular}{|c|c|c|c|c|c|c|c|}
\hline No. & $\begin{array}{l}\text { Primary tumor } \\
\text { site }\end{array}$ & $\begin{array}{l}\text { Tumor } \\
\text { invasion }\end{array}$ & Re-therapy & Recurrence & RT dose & $\begin{array}{l}\text { Nasopharyngeal } \\
\text { features under } \\
\text { endoscope }\end{array}$ & Survival \\
\hline 4 & $\begin{array}{l}\text { Nasopharyngeal } \\
\text { recess }\end{array}$ & $<180^{\circ}$ & $\begin{array}{l}\text { Re-irradiation } \\
\text { and } \\
\text { chemotherapy }\end{array}$ & Yes & $\begin{array}{l}67.5 \\
\text { Gy/30 } \\
F+54 \\
\text { Gy/27 F }\end{array}$ & $\mathrm{MN}$ & $\begin{array}{l}\text { Died of } \\
\text { complications } 2 \\
\text { months after } \\
\text { nasopharyngeal } \\
\text { necrosis }\end{array}$ \\
\hline 5 & $\begin{array}{l}\text { Nasopharyngeal } \\
\text { lateral wall }\end{array}$ & $\geq 270^{\circ}$ & Surgery & Yes & $\begin{array}{l}67.5 \\
\text { Gy/30 F }\end{array}$ & $\begin{array}{l}\text { Tumor } \\
\text { recurrence }\end{array}$ & Alive \\
\hline
\end{tabular}

\section{Figures}
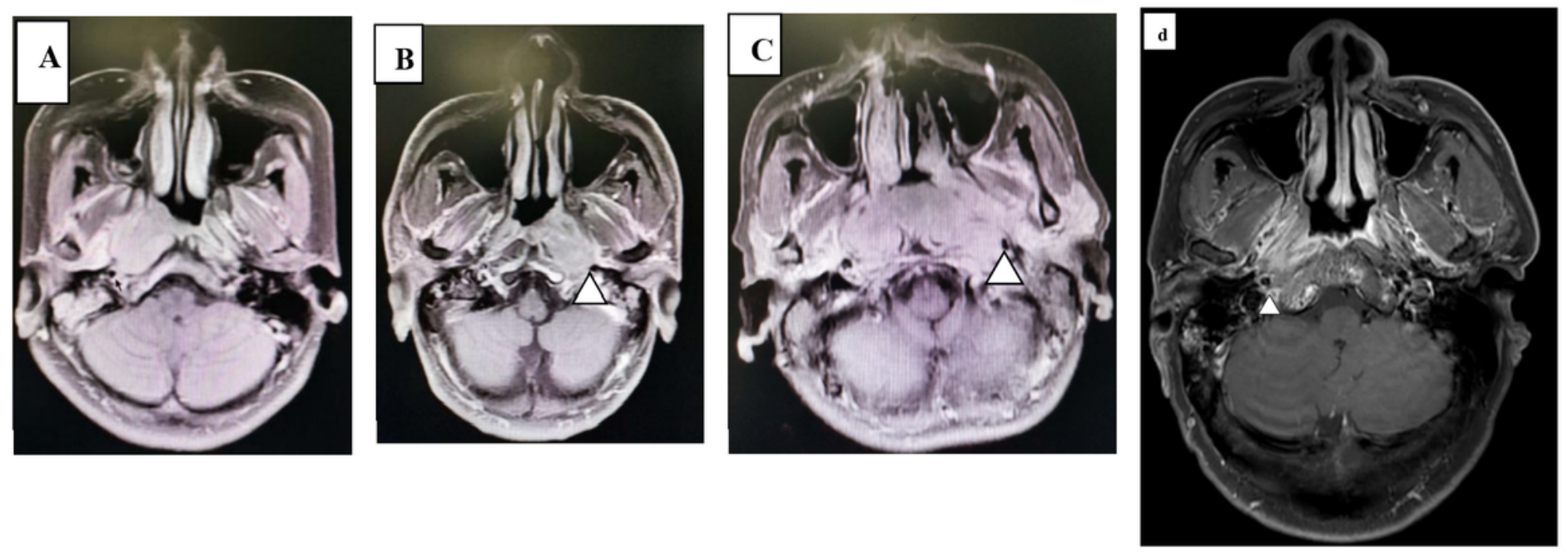

Figure 1

(A) T1WI-C MRI of the right-sided nasopharyngeal carcinoma before therapy, showing extensive involvement of the right prevertebral and pterygoid muscles with less than $180^{\circ}$ encasement of the right ICA. (B) T1WI-C MRI of the left-sided nasopharyngeal carcinoma before therapy, showing extensive involvement of the left prevertebral and pterygoid muscles with 
more than $180^{\circ}$ but less than $270^{\circ}$ encasement of the left ICA. (C) T1WI-C MRI of the bilateral-sided nasopharyngeal carcinoma before therapy, showing extensive involvement of the bilateral prevertebral and the pterygoid muscles with more than $270^{\circ}$ encasement of the bilateral ICA. Gaps between the tumor and carotid artery were wider after two induction chemotherapy treatments compared with the gaps before treatment (Fig.1-D-d). Notes: Arrowheads indicate the ICA; Abbreviations: MRI, magnetic resonance imaging; ICA, internal carotid artery; T1WI, T1-weighted imaging.
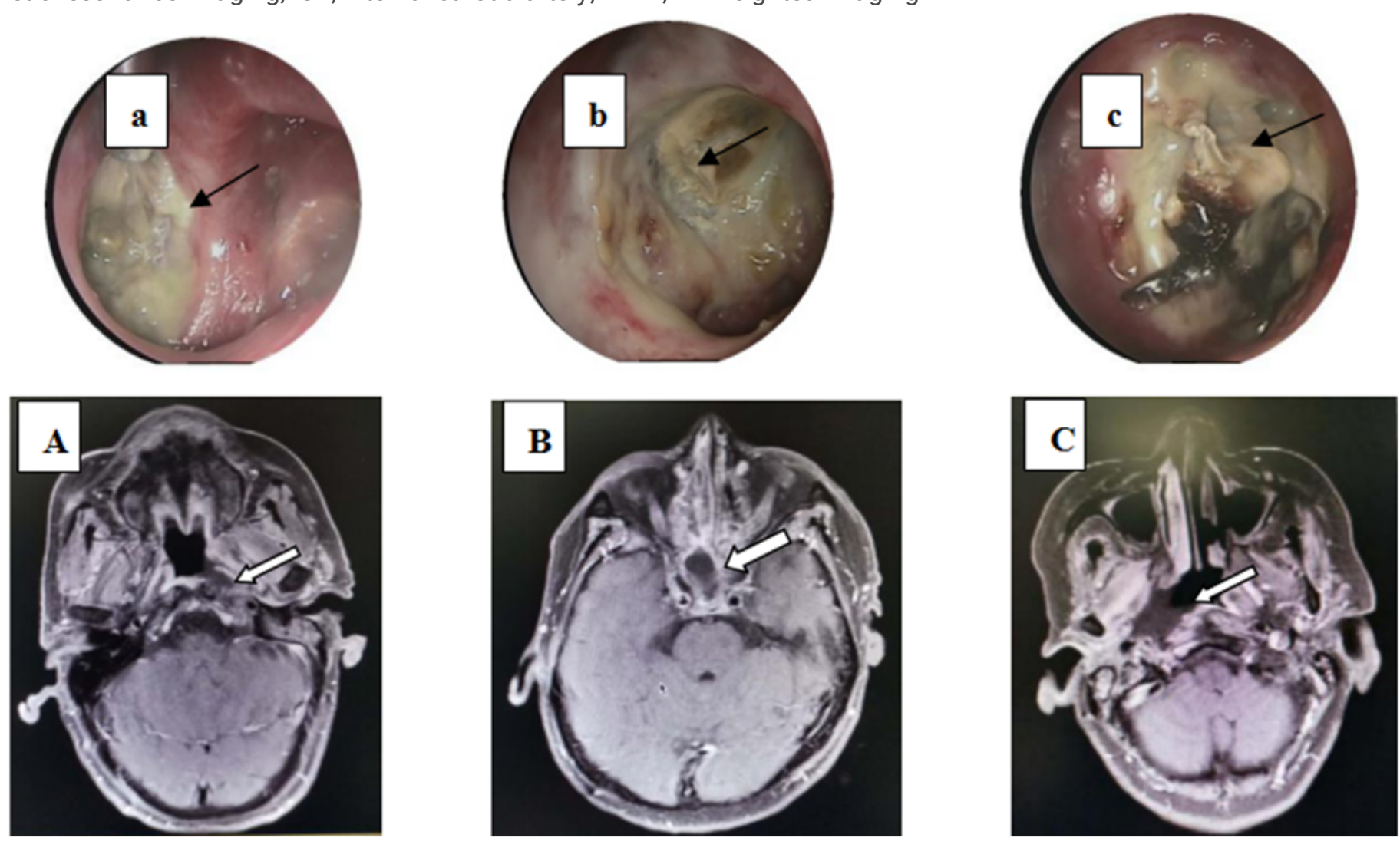

\section{Figure 2}

Endoscopic (a, b, c) and magnetic resonance (A, B, C) images of the three NPC patients with massive neck hemorrhage after radiotherapy. Endoscopic images show necrosis in the nasopharyngeal lateral recess and MRI images show the exposed internal carotid artery (arrows). 


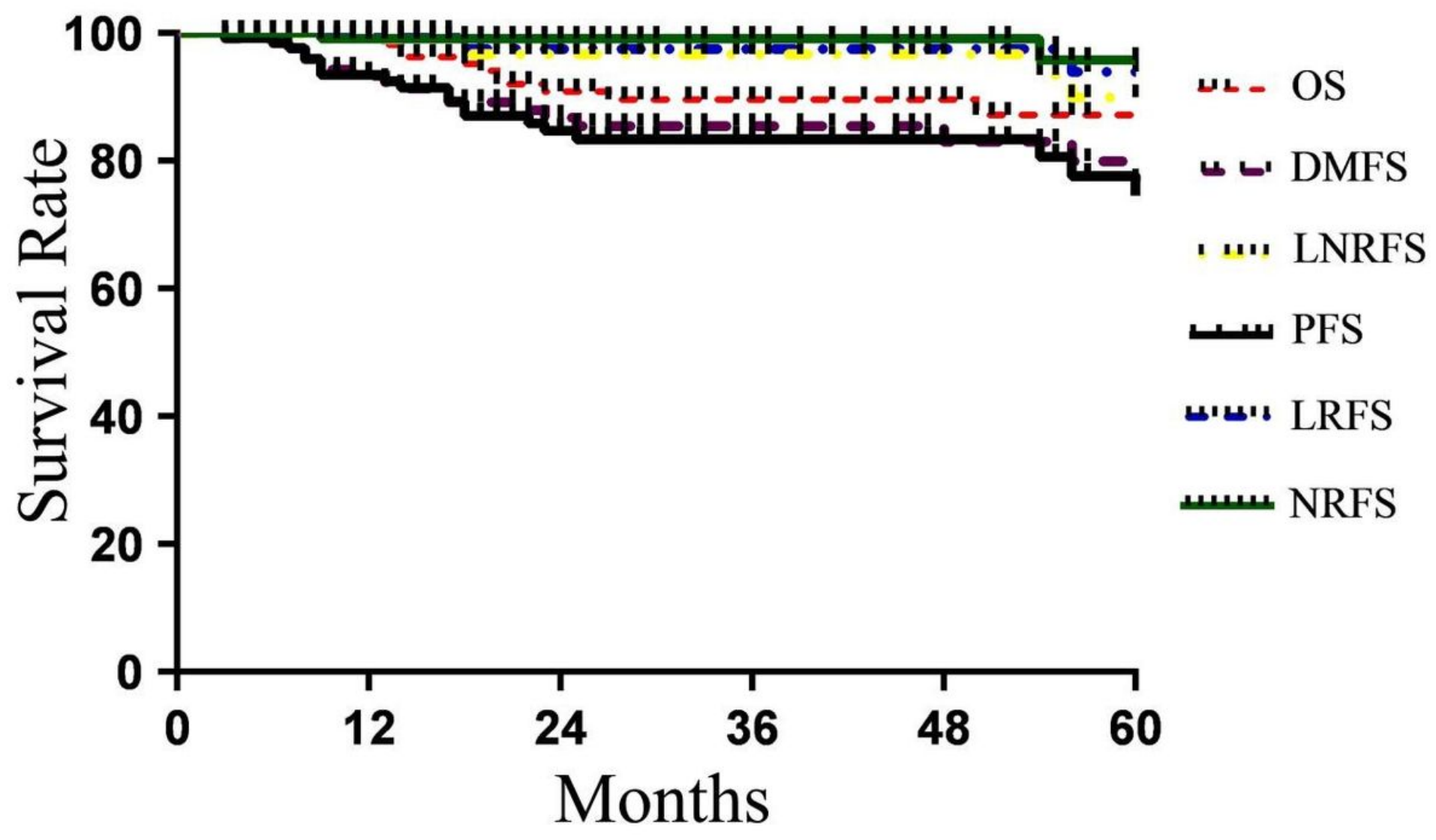

Figure 3

The 5-year survival rates of all patients

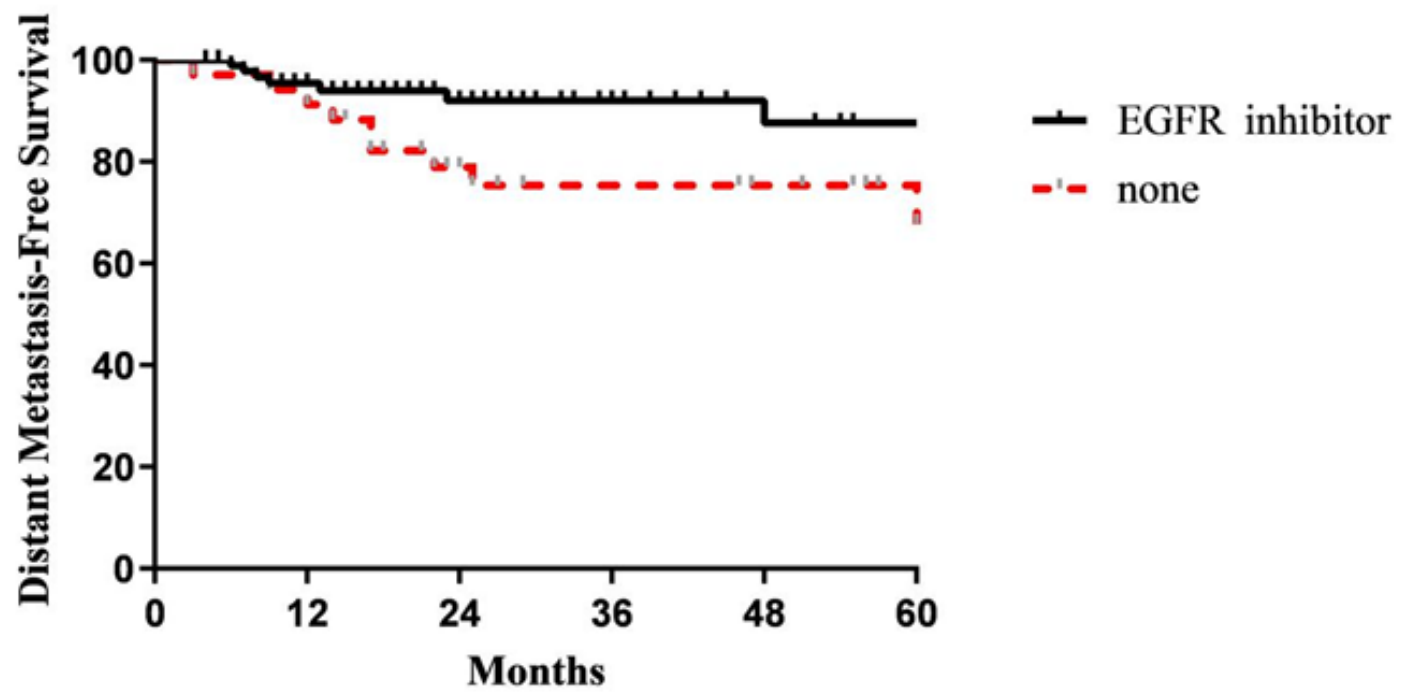

Figure 4 


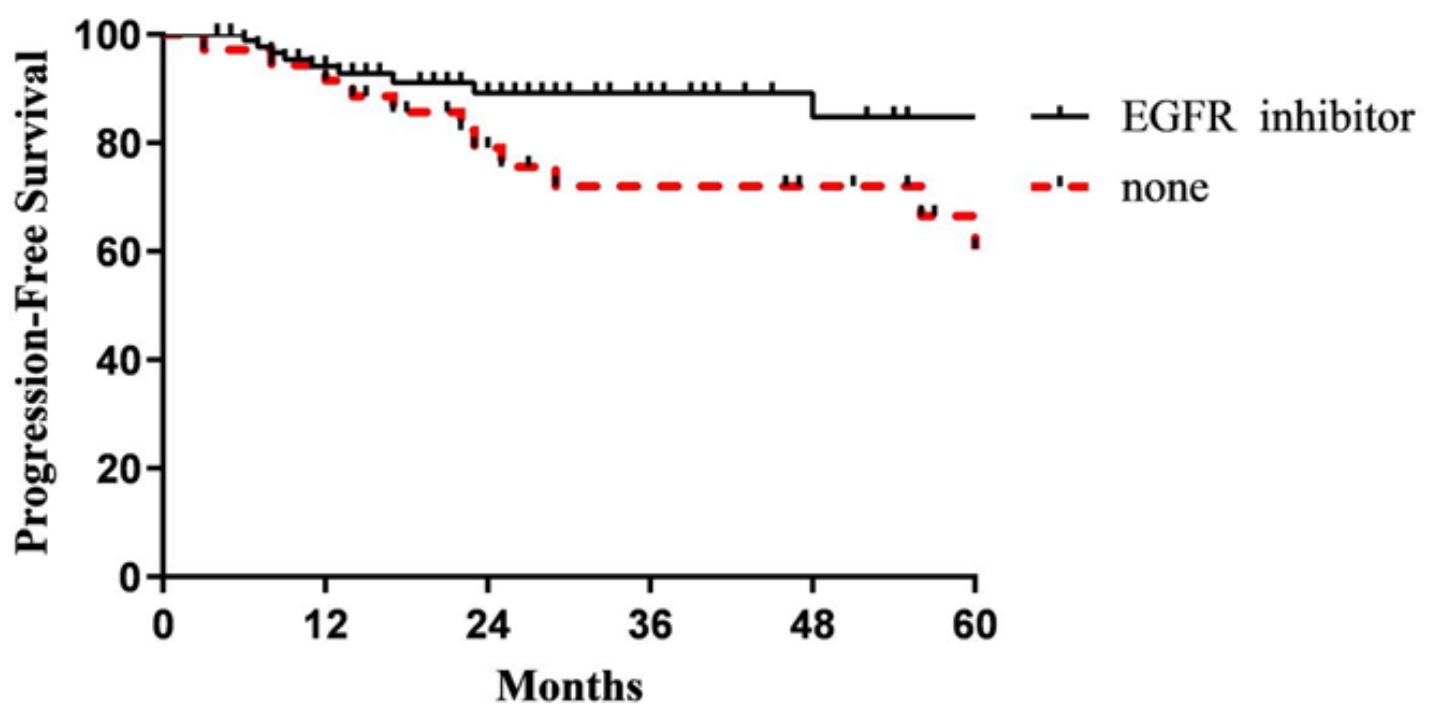

Figure 5

Comparison of PFS in patients with EGFR inhibitor or not $(\mathrm{P}<0.05)$

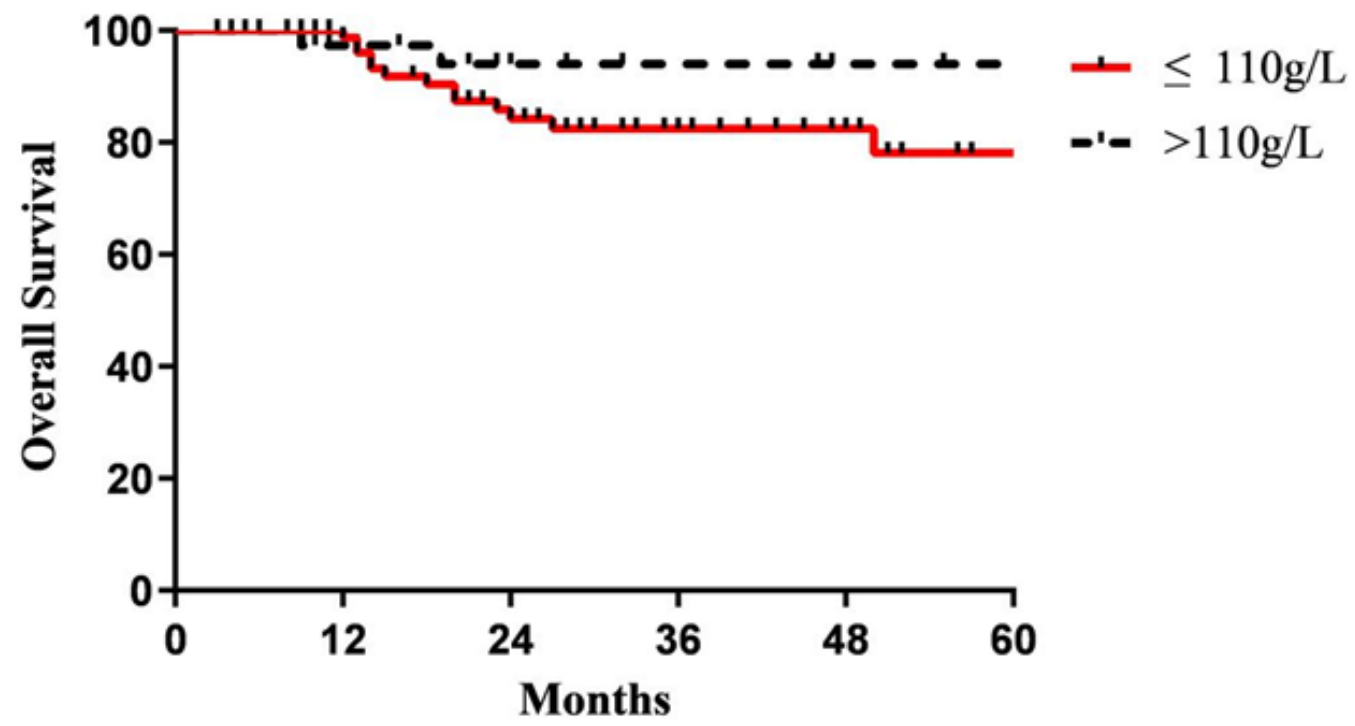

Figure 6

Comparison of OS in patients with hemoglobin levels $>110 \mathrm{~g} / \mathrm{L}$ and hemoglobin levels $<110 \mathrm{~g} / \mathrm{L}(\mathrm{P}<0.05)$ 


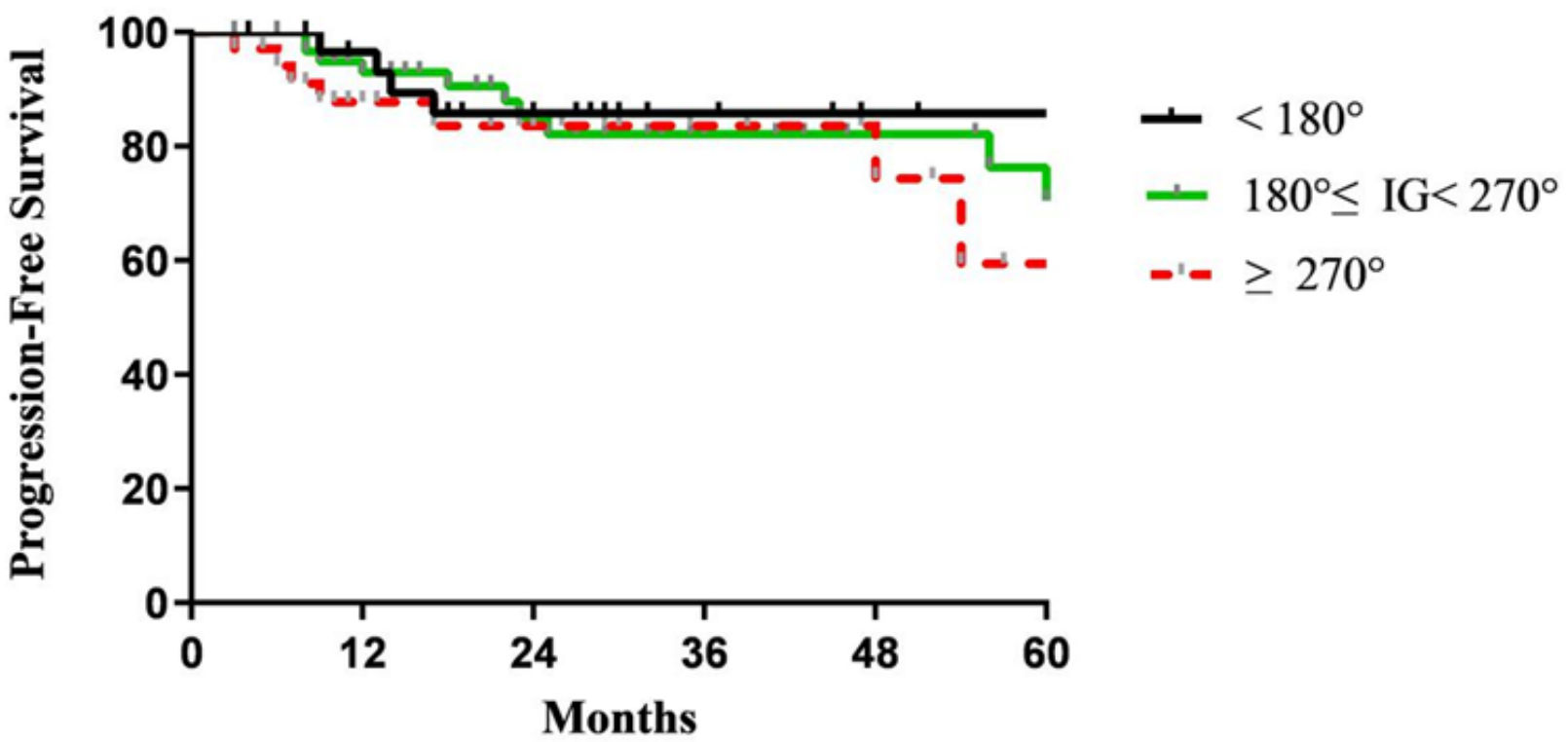

Figure 7

Comparison of PFS in three degrees of the carotid artery invasion $(P>0.05)$

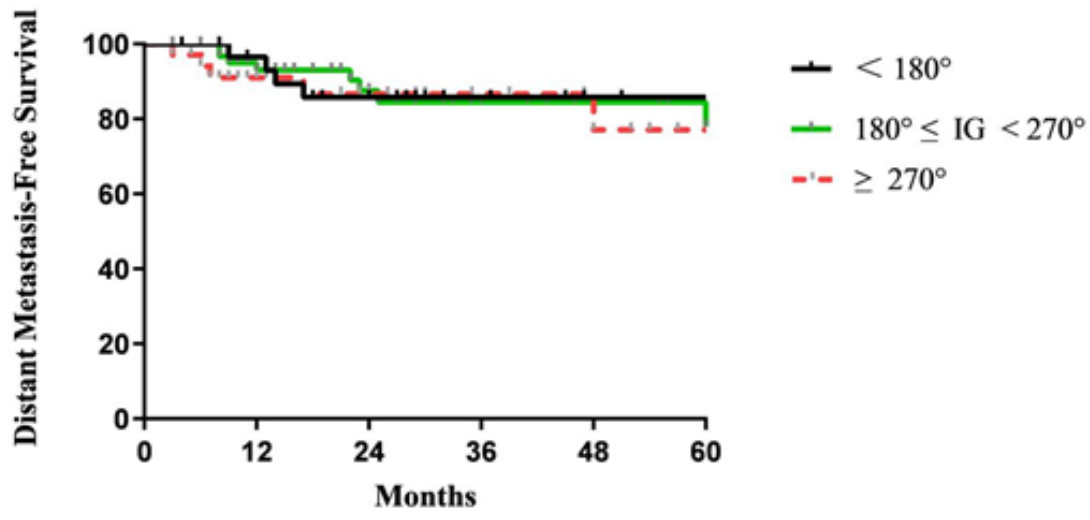

Figure 8

Comparison of DMFS in three degrees of the carotid artery invasion $(P>0.05)$ 


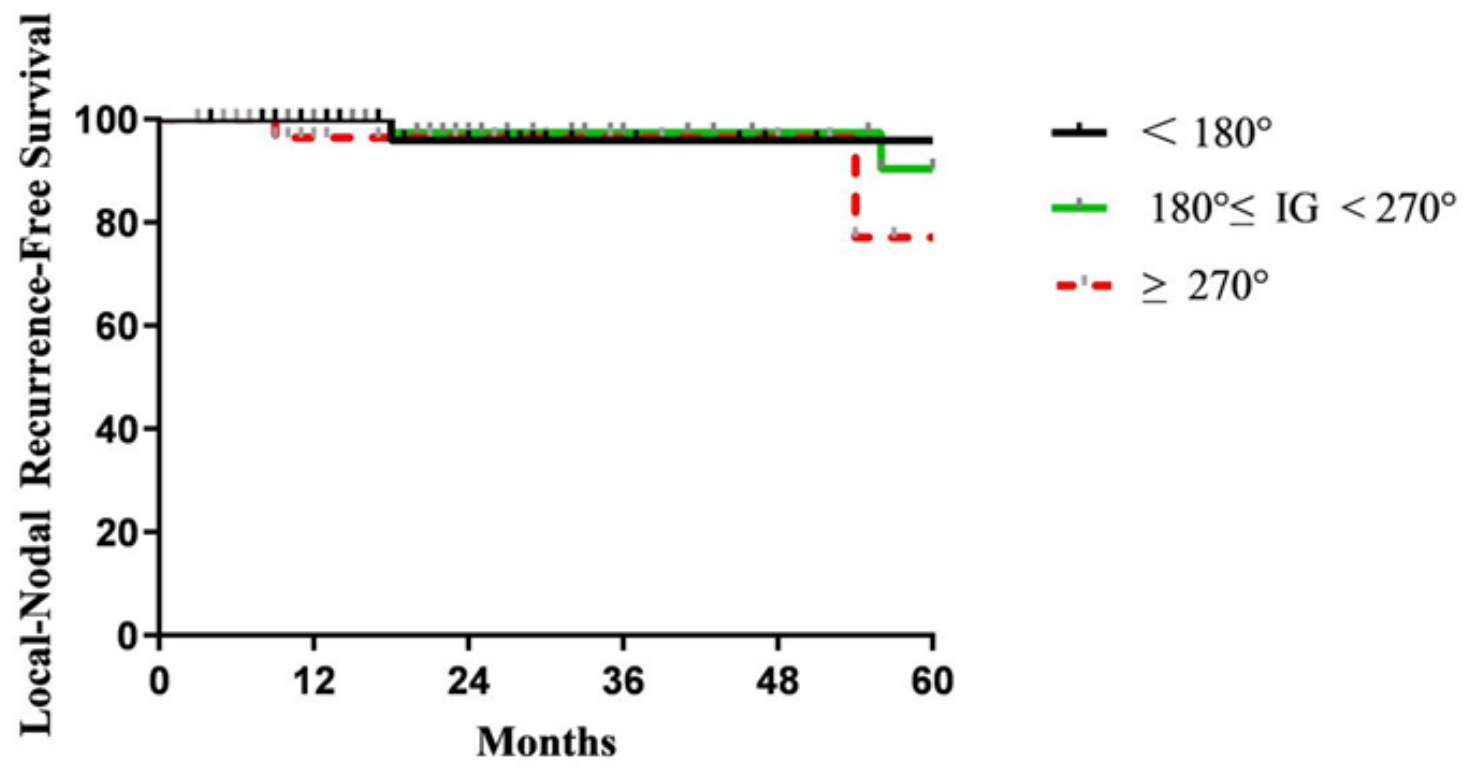

Figure 9

Comparison of LNRFS in three degrees of the carotid artery invasion $(P>0.05)$

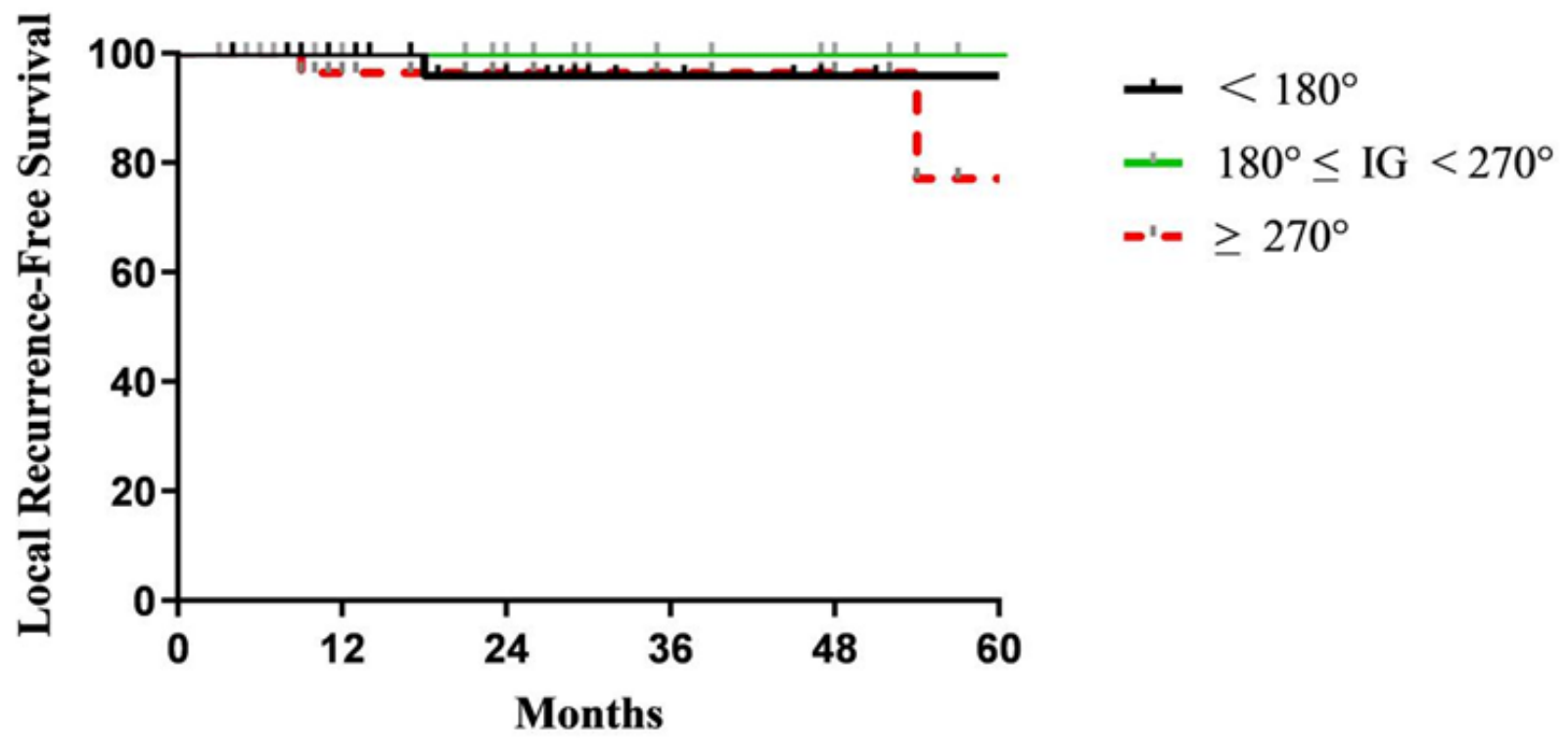

Figure 10

Comparison of LRFS in three degrees of the carotid artery invasion $(P>0.05)$ 


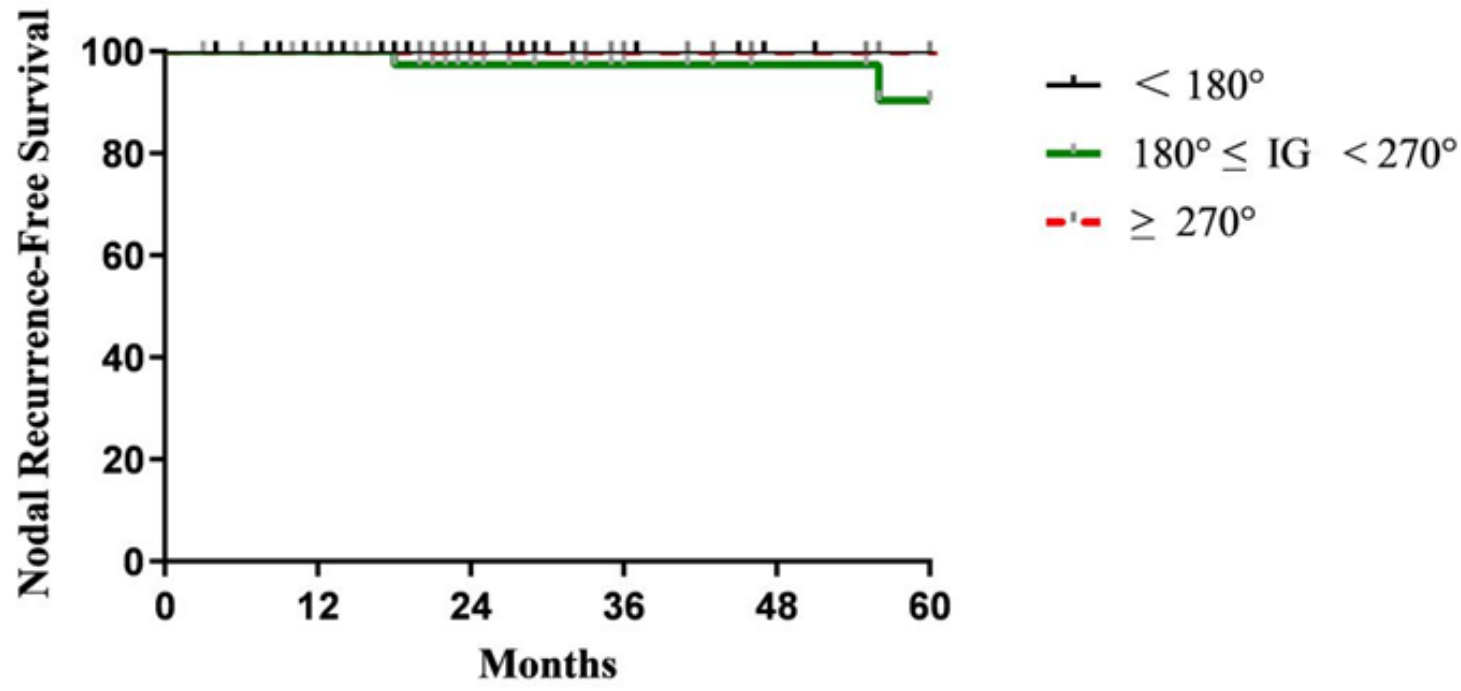

Figure 11

Comparison of NRFS in three degrees of the carotid artery invasior $\{P>0.05)$

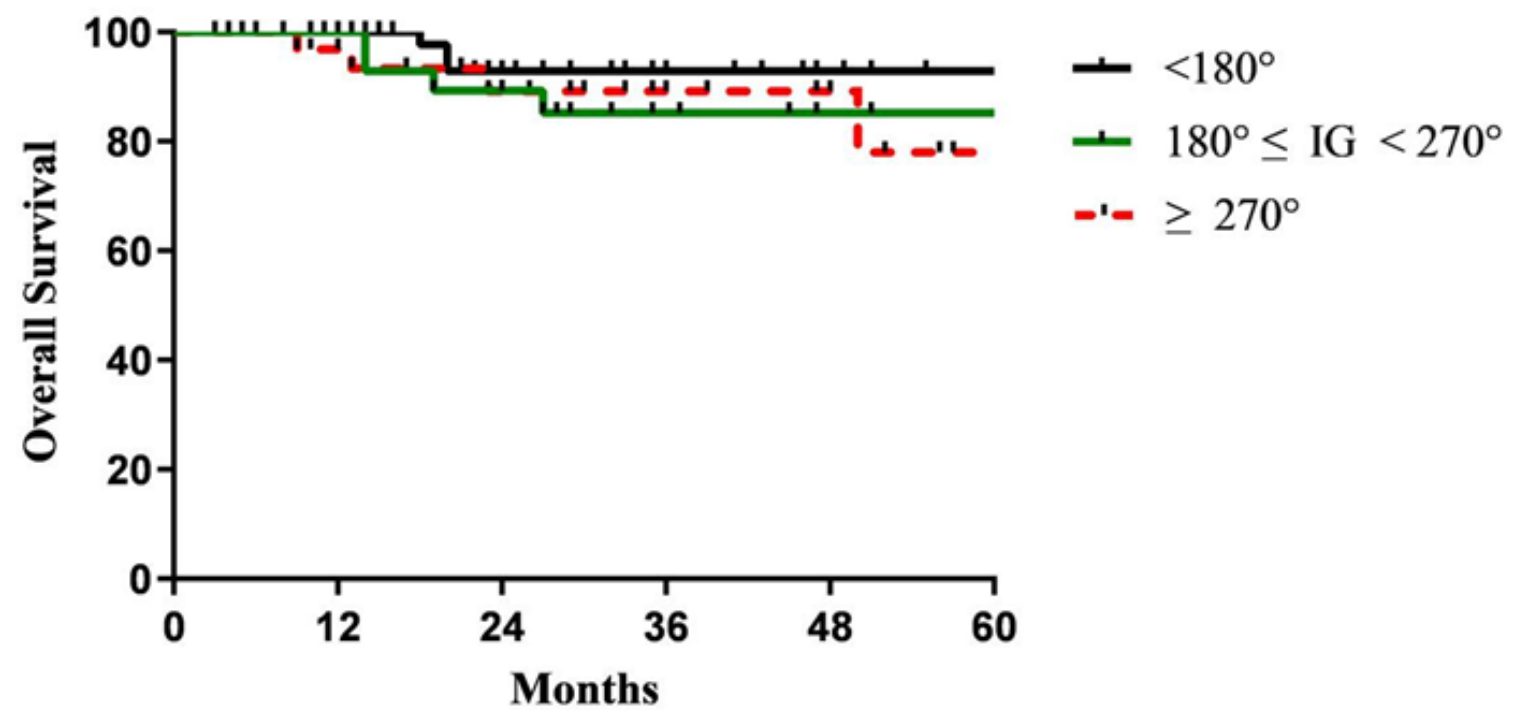

Figure 12

Comparison of OS in three degrees of the carotid artery invasion $(P>0.05)$ 